\title{
A Little lecture on the big burn: Bioenergy and the privatization of British Columbia's Crown forests
}

\author{
by Briony Penn ${ }^{1}$
}

\begin{abstract}
The combination of a gutted B.C. Forest Service, vast areas of not sufficiently restocked forest lands, a quirky loophole in the Kyoto Protocol and a provincial government ideologically driven to sell off public assets has created the perfect opportunity to burn down B.C.s forests in a biofuel boondoggle and the last barriers to privatization of B.C.s Crown forests. Interviews conducted with over a dozen ex-government foresters, industry representatives, contract foresters, silviculturalists, forest-sector round-table participants and political representatives point to this new direction that government is taking Crown forests-with no public consultation and media, like the government, that are failing to serve public interests. The voices of the whistle blowers point to a colossal failure of imagination by government that has implications to forest health, climate change mitigation and adaptation, other public interests in Crown lands from public access to biodiversity and water quality, First Nation interests, and international credibility on carbon accounting and standards and on certification. The lecture will explore the dystopic picture of what is planned and an alternative vision for Crown forests that has been put forward by the critics as a world leader in ecosystem services and valuation. The lecture notes were taken from an original longer article entitled The Big Burn, first published by Focus Magazine in August of 2010. ${ }^{2}$
\end{abstract}

Key words: British Columbia, not sufficiently restocked, cuts to the BC Forest Service, bio fuels, tenure reform, commercial forest reserves

\section{RÉSUMÉ}

Considérez d'un côté un Service forestier de la C.-B. désabusé, d'un autre les grandes superficies de forêts non adéquatement regarnies, une échappatoire originale dans le Protocole de Kyoto et un gouvernement provincial idéologiquement déterminé à se départir de ses actifs et vous avez loccasion idéale de mettre le feu aux forêts de la C.-B. avec l'espoir de créer des emplois bidons dans le secteur des biocarburants et d'abattre les dernières barrières empêchant la privatisation des forêts publiques de la province. Des entrevues réalisées auprès de plus d'une douzaine d'ex-forestiers gouvernementaux, de représentants de l'industrie forestière, de forestiers contractuels, de spécialistes en sylviculture, de participants à des tables rondes du secteur forestier et de porte-paroles de politiciens ont souligné cette nouvelle direction prise par le gouvernement relativement aux forêts publiques et ce, sans consultation publique ni diffusion dans les médias qui sont destinées, comme devrait lêtre un gouvernement, à protéger l'intérêt public. Les démarches des toutes premières sentinelles ont mis à jour l'absence totale d'imagination de la part du gouvernement pour ce qui touche la santé des forêts, les mesures de compensation et d'adaptation aux changements climatiques, les autres domaines publiques rattachés aux forêts publiques allant de l'accès au territoire forestier à la biodiversité et à la qualité de l'eau, les préoccupations des Premières Nations et la crédibilité sur la scène internationale en matière de comptabilité et de normes reliés au carbone et la certification. Ce texte explore l'image contre-nature de ce qui est prévu et la vision alternative des forêts publiques qui selon les critiques a été produite par un chef de file mondial en matière de bénéfices et d'évaluation des écosystèmes. Ce texte est une version remaniée d'un article plus long intitulé "The Big Burn », publié précédemment dans Focus Magazine en août 2010. ${ }^{2}$

Mots clés : Colombie-Britannique, insuffisamment régénéré, coupures réalisées dans le Service forestier de la C.B., biocarburants, réforme de la tenure, réserves de forêts commerciales

The Doug Little Memorial Lecture series was initiated by the faculty of Natural Resources and Environmental Studies at the University of Northern British Columbia (UNBC) in the fall of 1996. This annual event commemorates the late J.D. Little, former Senior Vice-President Forest Operations, Northwood Pulp and Timber Limited. Doug was a founding supporter of UNBC and a recipient in 1986 of the distinguished forester award from the association of British Columbia Professional Foresters. Doug Little's philosophy was that with appropriate forest management, the resources of the forest can be sustained for future generations. The lecture series is supported by an endowment from Northwood Pulp and Timber Limited now Canfor.

\footnotetext{
${ }^{1} 119$ Clarinda Rd., Saltspring Island, British Columbia V8K 1W8.

${ }^{2}$ http://www.focusonline.ca/?q=node/71
} 


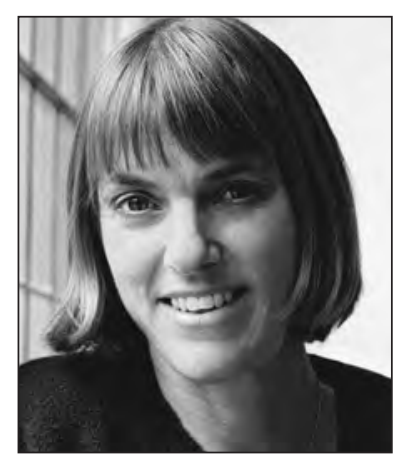

Briony Penn

\section{Background}

On August $20^{\text {th }}, 1910$, a huge wind blew off the Cascades and whipped hundreds of forest blazes into an inferno that extinguished towns and three million hectares of forests. The fires came at a critical time in United States history, when the timber barons, including Weyerhaeuser, were swaying public opinion towards privatizing the country's public forests. The timber barons had attacked Teddy Roosevelt's new forest service and its backbone-the forest rangers. Roosevelt's mandate that "the forest reserves should be set apart forever for the use and benefit of our people as a whole and not sacrificed to the short-sighted greed of a few," was undermined by claims that Roosevelt's "green rangers" (led by chief forester Gifford Pinchot) were "google-eyed, bandy-legged dudes, sad-eyed, absent-minded professors and bugologists." When the fires came, Teddy's forest rangers fought the fires, saved thousands of lives, and turned the tide against privatization. It led to the strengthening of the forest service and its duty of stewardship. It was called the year of the Big Burn and out of its ashes also came the creation of the British Columbia Forest Service, with a similar mission and structure.

A century later, history is repeating itself in B.C. The forest service has been decimated with a decade of cuts rendering it unable to do its job. The pressures for privatization are coming from the same companies, like Weyerhaeuser, to meet $21^{\text {st }}$ century demands for cheap so-called "green" biofuel and real estate. And the champions for our public forests are the latest generation of "green rangers"-minus a Roosevelt-blowing the whistle on an industry-controlled government, poised to put out what could become the Second Big Burn.

While the political winds were changing, the climatic winds were blowing in profound effects on our forests. Interior forests experienced huge hits from record wildfires, mountain pine beetle, other large-scale insect infestations like western spruce budworm, and diseases like Dothistroma. The mountain pine beetle alone has damaged 15 million hectares, $30 \%$ to $60 \%$ of which staff estimate are not satisfactorily restocked (referred to as NSR lands). Fires have burned over a million hectares. A third of a million hectares have been left unstocked from small-scale salvage logging without obligation to reforest.

The "green rangers" are a cohort of influential and wellrespected professional foresters from the forest service led by Anthony Britneff, 39 years as a senior professional in the forest inventory, silviculture and forest health programs of the service. He expresses the sentiment of the group. "This government might think that by rendering the Forest Service dysfunctional and by not investing in the renewal of forest lands, it will eventually rationalize the privatization of provincial forests at fire-sale prices. Enclose the commons? Wake up B.C.!"

Jim Pojar, provincial forest ecologist for over 25 years out of Smithers, and internationally regarded specialist on B.C.'s ecosystems, states "Government wants to deregulate and effectively privatize our public forests, presenting 'hard times' with forest die-off and declining revenue from forestry as a convenient rationale to impose the ideology. Their vision seems to be to maximize the net present value of forest resources, liquidate as much wood as quickly as possible, manage only for fibre or biomass, sell off forest land to industry and let them deal with the hassle-and maybe make some extra money in real estate. If that is your vision, you don't need a forest service and you don't need a regulatory and management regime."

Del Meidinger, chief provincial forest ecologist for 30 years whose work with forest classification systems led the world as a management tool and won him the Premier's Legacy Award, asks "Why are they de-emphasizing forest stewardship? The forests support so many ecosystem services. Really what is at stake is the protection of the public interest in our forests." Adjunct professor of forestry with an Emeritus position in the forest service, Alan Vyse at Thompson River University in Kamloops, states, "The facts stand for themselves. There are lots of concerns out there about the change in culture surrounding our public forests and I share them. What we need now with all the challenges of increased pests, fire and other climate change issues is an informed and proactive forest service to identify and solve the problems."

Pojar has recently written a scientific report, New Climate for Conservation, peer-reviewed by international climate scientists like Dr. Andrew Weaver and Dr. Jim Hansen, highlighting the challenges facing B.C.'s forests from climate change. Our healthy ecosystems are already impacted and will cause dire consequences for fragmented or degraded ecosystems. As Vyse points out, "How do you meet these challenges when you reduce your staff and researchers? In the various cuts including the latest one, they have eliminated 1500 years of accumulated expertise in technical issues. How can you be proactive and justify these cuts?"

The evidence for this new direction comes from internal ministry documents, which describe the new mission statement for the Ministry - "to provide a superior service to resource stakeholders by supporting competitive business conditions" giving priority to "Enhancing industry competitiveness" and "Identifying clear outcomes for investors." An earlier internal memo dated June 9th, 2009 clearly articulates the new single-function mandate of the forest service of "fulfilling our role as advocates for the forest industry." This may have been true in the past, but it was never written boldly on the bottom of the stationary.

From insider info prior to the latest round of ministerial reorganization, from the 42 district offices that used to exist before the BC Liberals took office in 2001, only 22 remain. According to the BC Government Employees' Union, released in their new campaign aimed at the Crisis in $\mathrm{BC}$ Forests, so far 1004 staff have been cut since 2002-well over half of these to the district staff providing stewardship, forest management, recreation, monitoring, enforcement and compliance services on the ground.

The ministry has been unable to provide the total number of staff remaining. Insiders speculate that staffing levels are now at record lows, possibly below half the staffing level in 1981 at the height of the last recession. The remaining district offices are now responsible for over two million hectares-a ratio of forester to forest that is 1000 times greater than in 
Sweden. Since 2002 and in addition to staff cuts, most forest management programs have had budgets slashed by over $50 \%$. The amount of public spending on reforestation dropped by $93 \%$ in 2002 and has only recovered to about $40 \%$ of the budgets in the '90s while the amount of lands that need reforestation have increased more than fiftyfold.

No one knows anymore how much land is not stocked or requires replanting. Britneff estimates that conservatively 9 million hectares, an area three times the size of Vancouver Island, is not stocked adequately with trees-lands that are outside of licensee responsibilities and therefore the responsibility of the province-and between 3 and 6 million hectares of that area would be economically feasible for replanting. How can you reliably determine timber supply if you don't have a good inventory of what is there and what isn't? A lack of public reporting prevents even a coherent discussion about the numbers because they aren't available to manipulate.

With the new Ministry of Natural Resource Operations taking over all licensing of resource projects, the reorganization and amalgamation of the other resource ministries into policy agencies, and the elimination of the Research Branch, the Forest Service is now virtually gone. An internal email to staff explains: "This new structure will streamline government processes for critical natural resource industries to better attract global investment and turn proposed projects and investments into actual worksites and jobs." The district offices now are renamed FibreConnections BC, where fibre queries will be directed to one of 72 fibre officers who "will triage the requests, provide information and bring together buyers, sellers and investors where applicable."

Harry Drage, another "green ranger" with 32 years in the forest service in the southern interior as district manager, provincial recreation officer and certification inspector, observes, "If you take it one step further and look at the staffing in both the ministries that are charged with the stewardship-forest and environment-it is down by well over a half of what it was. This creates a lack of public oversight and so the checks and balances are not there anymore. We aren't protecting the public interest. Are the public comfortable with that?"

Fact-checking the numbers is challenging. The political decision to strip out a requirement for resource analysis reporting from the Ministry of Forests and Range Act has left the public with limited and confusing facts. After 2002, the Ministry's Annual Reports shrink in half and reporting on forest management activities takes a downward dive. John Betts, head of the Western Silvicultural Contractors' Association, remarks that the last time there were such slim Annual Reports in content was when the forest rangers were fighting on the Western Front in World War 1, having put out the fires back at home.

Betts reports, "We have lost $30 \%$ of our work and guys are losing their jobs. The lumber market has collapsed so there is no work with the companies but the point is we should be busier than ever from government because we have a major restoration project that is being neglected." Typically, investment in restoration is made during downswings when labour is abundantly available.

Norm Macdonald, NDP MLA and Opposition Forest Critic comments, "This is the most valuable asset that the people of $\mathrm{BC}$ have- just the timber value of the forest alone is a third of a trillion dollar-and, if we don't maintain that investment with regard to reforestation and research, matters will become progressively worse. [Our forest service] has been gutted to the point that the work that is needed to be done isn't getting done."

Macdonald sees the change in direction as the thin end of the wedge towards the privatization of public forests. "This is croneyism at its worst. The memorandum sent out to all the forest managers to only focus on industry interests has had no public discussion. Has the public interest been considered? Is access going to be denied? To have that agenda without public discussion is deeply disturbing. After nine years on this file, you would think there would be a public plan? At best it is incompetence, at worst there is something more nefarious like a privatization agenda of our public lands."

\section{The Privatization Agenda}

Minister of Forests, Pat Bell, makes no apology for the cuts or changing the culture. With a 35\% reduction in harvest levels and dropping government revenues from forestry, he feels the reduction in staff is not unreasonable even though it is pointed out that the cuts started before the recession. "I've been very clear in the direction we need to go: better utilization of the resource, including bioenergy." The main requirement of the bioenergy sector is secure long-term tenures on productive lands close to markets ostensibly to provide assurance to investors that there will be a return on capital employed. Bell maintains there are no plans to privatize Crown forests, but it is no secret that they have plans for tenure reform using a commercial forest reserve concept. According to Britneff, granting of long-term, intensive silviculture leases that preclude any other uses are de facto privatization. Regarding the commercial forest tenures, Bell is vague. "We envision them as smaller geographical areas where you don't have complications of species at risk, traditional-use areas, and other values."

Recommendations from the Woodbridge Report, released at the BC Business Council of BC 2020 Summit in October of 2009 , stated that industry was primarily interested in tenure reform and putting investment interests as the top priority. Industry is only interested in the most productive forest lands of valley bottoms, where in fact all those "complications" exist. Forest geneticist to industry, Dr. Jean Brouard, states, "You can only grow trees like poplars profitably in moist bottom valley lands and that might coincide with species at risk or fish habitat values. There are also big concerns with pathogens [disease like Septoria musiva] in hybrid poplar plantations that could jump to native cottonwoods and create a problem for our native forests. The first thing you need, of course, is good inventory of all your lands." So even if the government wants to implement its own plans to privatize, it now lacks credible inventory information.

The recommendations of the Woodbridge Report echo exactly those of the Working Roundtable on Forestry, set up by Bell, which published its report the year before. Of the 15 members, 12 were industry representatives. The lone academic, Derek Thompson, also a former deputy minister, stated that "tenure reform dominated the discussions, but we couldn't even get consensus with just industry folk at the table." Thompson recounts why. "There was a great deal of trepidation from government about taking the discourse into 
the public realm because of the potential for uncontrollable controversy." Tenure reform is critical because industry also wants the ability to sell real estate should the biofuel industry not pay off. The B.C. forest industry is poised for this type of asset liquidation.

Most of B.C.'s forest industry is now controlled by "vertically integrated" investment firms specializing in asset liquidation. In 2007, Third Avenue Management LLC, out of New York became the largest shareholder in B.C.'s two pulp and paper companies, Canfor and Catalyst adding to its existing shareholdings through Third Avenue Trust in Timberwest, Weyerhaeuser and Brookfield Assets Management, (Jimmy Pattison, one of the other big shareholders of Canfor, sits on BAM's Board) one of the largest real estate companies in the world, which in turn has interests in Western Forest Products and Island Timberlands (who have been liquidating and flipping private forest lands in southern Vancouver Island since government dissolved the TFL requirements).

In 2009 , half (40 million cubic metres) the provincial Annual Allowable Cut (AAC) was controlled by 10 large licensees with the top two ranked licensees (Canfor and Western Forest Products) controlling slightly less than half this amount. This means that when the AAC for Weyerhaeuser (ranked \#6) is added to the combined AAC for Canfor and WFP, Third Avenue Management LLC of New York controls over $25 \%$ of B.C.s public harvesting rights. Is this foreign concentration of tenure rights in the public interest? And is the Ministry of Forests, Mines and Lands, as the "advocate of industry", now bound to deliver more of these types of lucrative opportunities for liquidation, concentration and consolidation at the expense of the public interest?

And what is the future in biofuels? How can burning the sinks - and using a fuel composed of carbon-possibly be good for the atmosphere? It goes back to a strange loophole in the Kyoto Protocol that enables Canada to opt out of forestry carbon accounting (Searchinger et al. 2009.). A tree can be cut down, turned into wood pellets, shipped overseas and then burned as fuel without having to account for any of the carbon that is released through all these activities. If the loophole were plugged tomorrow, B.C. would be forced to account for emissions from logging and slash burning, which in the 2007 BC Greenhouse Gas Inventory Report is the single largest source of emissions, larger than the energy sector. The entire dream of rescuing the B.C. forest industry through biofuels would go up in a puff of wood smoke.

Ontario is already taking the lead on this loophole in its proposals to revitalize ailing pulp mills and send wood pellets to the coal-fired power plants, which are legislated to stop using coal by 2014. It is one way to keep traditional forest jobs in forest-depressed towns, but it is politically risky and from the perspective of industry, is it the beetle-damaged northern indigenous forests far from markets that industry is after?

Peter Woodbridge points out that B.C. has to follow the more competitive suppliers of fibre and biofuel feedstock, i.e., intensive plantations, such as they have in the United States and Europe. "Plantations are a dirty word for some Canadians," he observes, but states the business case about why there is no alternative, "To remain competitive, B.C. has to lower wood costs and this is not done through selling indigenous timber cheaper. Because our labour and transport costs are going up, we have to farm fibre and feedstock for biofuels more intensively. We need to find a secure tenure system to do this." Industry wants the privatization piece-or something that will provide full protection of the investment.

John Rustad, MLA in charge of silviculture, identifies new intensive technologies as the answer because they increase fibre yield by $20 \%$ on productive sites, and points to some of the pilot examples, such as the hybrid poplar plantations in the Fraser Valley area by Kruger, [Scott Paper] on private lands. Woodbridge highlights the recent WeyerhauserChevron venture company called Catchlight Energy. Catchlight is "combining Weyerhaeuser's expertise in innovative land stewardship, resource management and capacity to deliver sustainable cellulose-based feedstocks at scale with Chevron's technology capabilities in molecular conversion, product engineering, advanced fuel manufacturing and fuels distribution." GreenWood Resources, which develops intensively-managed hybrid poplar technology with plantations just over the border, is in the portfolio of ex-Dean of the Faculty of Forests at UBC, Clark Binkley, advisor and proselytizer on the privatization of Crown forests before returning to United States and setting up his own investment company, International Forestry Investment Advisors.

It isn't just the scientists and "green rangers" that are nervous about the dismantling of the forest service. Woodbridge notes, "I am recommending that government also beef up the forest service oversight. Let companies have their own sand box and manage their fibre as they see fit, but they have to stay within the confines and rules set by government. I am an advocate for good planning and strong government oversight and in this regard I have some criticisms of government." Brouard points to the alternative, which is the Great Bear Rainforest (GBR) Agreement, where the companies make an agreement with ENGOs and First Nations, essentially bypassing government altogether and "leaving government to play catch-up."

In the coastal forests of the GBR, with the highest storage of carbon in the world and a key global asset for conserving biodiversity, coastal First Nations are working out the first carbon-sharing agreements - this time through conservation, restoration or improved forest management projectsthrough international voluntary carbon standards. Derek Thompson, who is now negotiating carbon conservation projects in the tropics, says that what amazes him about the government is the sheer lack of attention, support and public discussion about something as potentially huge as a revenue source as carbon projects on the conservation end.

Alan Vyse points to the fact that regardless of the type of future business interests from biofuels to ecosystem services, and whether the government is relying on professional reliance, accreditation or international standards, "where is the discussion about what those public interests are? It is way past time for some fairly significant discussions on the future of our public forests." Will it create an "uncontrollable controversy"? It is hard to imagine anything worse than if the public weren't consulted.

The voices of the whistle blowers point to a colossal failure of imagination by government that has implications to forest health, climate change mitigation and adaptation, other public interests in Crown lands from public access to biodiversity and water quality, First Nation interests and international credibility on carbon accounting and standards. At a time 
when our top scientists are telling us we have to save sinks and stop emissions, we are preparing to chop down sinks and release their emissions. Secondly, doing this with huge political and economic risk. Third, instead of investing in the valuable work of restoration and conservation at a time when labour and communities could most benefit from it, we are abandoning the more marginal areas and threatening to sell off the highest productivity areas that have values globally in climate change mitigation and adaptation. Fourth, this is being proposed with no oversight or public consultation that even industry is nervous about and can't reach consensus on.

The consensus coming from the green rangers is that we have the ability to turn B.C. around and back into a world leader in climate change action. We still have the landbase, unconverted native forests, the expertise and shared cultural values of fairness, justice and stewardship. The year before the B.C. Forest Service was gutted, a group of the green rangers proposed these ecological principles govern the management of our Crown lands.

1. Make ecological sustainability the fundamental objective of forest management.
2. Use a hierarchy of scales when planning forest practices.

3. Establish a rate-of-cut that does not compromise the longterm ecological integrity of landscapes and watersheds.

4. Engage local communities and incorporate local knowledge in establishing decision-making processes and in planning forest management.

5. Conserve all native species and their habitats within the range of natural variability.

6. Protect rivers, lakes, estuaries and marine shores.

7. Focus silvicultural systems primarily on what is retained rather than on what is removed.

8. Incorporate ecological restoration of degraded landscapes, stands and sites into forest management.

9. Acknowledge uncertainty and monitor the ecological consequences of forest practices.

\section{References}

Searchinger, T.D. et al. 2009. Fixing a critical climate accounting error. Science 326: 527-528. 